\title{
Pengembangan LKPD Berbasis Pendekatan CTL pada Materi Teks Hasil Laporan Observasi Kelas X SMA
}

\section{Novia Miftakhul Mimma Aprilda1*, Ade Kusmana², Rustam}

1,2,3 Program Magister Pendidikan Bahasa Indonesia FKIP UNJA, Jambi, Indonesia

\section{ARTICLE INFO}

\section{Article history:}

Received September 12, 2021

Revised September 13, 2021

Accepted October 14, 2021

Available online October 25, 2021

Kata Kunci:

Hasil Belajar, LKPD, Pendekatan

CTL

\section{Keywords:}

Learning Outcomes, LKPD, CTL

Approach

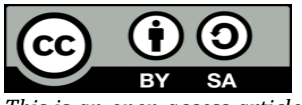

This is an open access article under the CC BY-SA license.

Copyright (C) 2021 by Author. Published by Universitas Pendidikan Ganesha.

\begin{abstract}
A B S T R A K
Kesulitan yang dialami oleh siswa selama proses pembelajaran daring cenderung disebabkan karena kurangnya penggunaan media serta inovasi guru dalam kegiatan beajar, sehingga untuk mengatasi hal tersebut dibutuhkan suatu media pembelajaran yang dapat memaksimalkan proses belajar. Berdasarkan hal tersebut maka tujuan dari penelitian ini yakni untuk mengembangkan Lembar Kerja Peserta Didik (LKPD) berbasis pendekatan CTL pada materi teks hasil laporan observasi kelas X SMA. Penelitian ini merupakan penelitian dan pengembangan yang menggunakan model ADDIE yang terdiri dari 5 tahap yaitu analisis, desain, pengembangan, pelaksanaan, dan evaluasi. Subjek penelitian ini adalah siswa kelas X SMA yang berjumlah sebanyak 22 orang siswa. Dalam penelitian ini, dilakukan uji coba perorangan yaitu dengan satu orang guru, uji coba produk pada kelompok kecil yang terdiri dari 8 orang siswa dan uji coba kelompok besar terdiri dari 22 orang siswa. Instrumen yang digunakan dalam penelitian ini adalah angket validasi ahli dan angket uji coba perorangan, uji coba kelompok kecil dan uji coba kelompok besar serta tes hasil belajar siswa. Analisis data penelitian ini dilakukan dengan menggunakan statistik deskriptif. Hasil yang diperoleh pada penelitian ini menunjukkan bahwa media LKPD memiliki validitas sangat tinggi. Selain itu LKPD berbasis pendekatan CTL juga dapat meningkatkan hasil belajar siswa dari $<55$ menjadi 86. Sehingga berdasarkan hasil tersebut dapat disimpulkan bahwa LKPD berbasis pendekatan CTL layak untuk dikembangkan dan dibelajarkan kepada siswa kelas X SMA karena dapat meningkatkan hasil belajar bahasa Indonesia siswa.
\end{abstract}

\section{A B S T R A C T}

The difficulties experienced by students during the online learning process tend to be caused by the lack of media use and teacher innovation in learning activities, so to overcome this, a learning media is needed that can maximize the learning process. Based on this, the purpose of this study is to develop a Student Worksheet (LKPD) based on the CTL approach on the text material from the observation report for class X SMA. This research uses the ADDIE model, which consists of 5 stages, namely analysis, design, development, implementation, and evaluation. The subjects of this study were students of class X SMA, totalling 22 students. In this study, individual trials were conducted with one teacher, product trials in small groups consisting of 8 students and large group trials consisting of 22 students. The instruments used in this study were expert validation questionnaires and individual test questionnaires, small group trials and large group trials, and student learning outcomes tests. The data analysis of this research was carried out using descriptive statistics. The results obtained in this study indicate that the LKPD media has very high validity. In addition, the LKPD based on the CTL approach can also improve student learning outcomes from $<55$ to 86. So based on these results, it can be concluded that the LKPD based on the CTL approach is feasible to be developed and taught to class X SMA students because it can improve students' Indonesian language learning outcomes.

\section{PENDAHULUAN}

Pendidikan mempunyai peranan penting dalam kehidupan. Pada era globalisasi yang dirasakan saat ini terlihat bahwa pendidikan menduduki tingkat teratas, hal ini dikarenakan pendidikan dapat menentukan kualitas seseorang. Pendidikan erat kaitannya dengan belajar dan pembelajaran (Izma \& Kesuma, 2019; Shidiq \& Raharjo, 2018). Proses pembelajaran yang dimaksud yakni berupa kegiatan aktif untuk mencapai suatu tujuan tertentu, dimana belajar merupakan suatu bentuk perilaku yang kompleks (Pane \& Dasopang, 2017). Pada umumnya kegiatan pembelajaran dilakukan melalui proses tatap muka langsung antara guru dan siswa, hanya saja dengan adanya pandemic covid-19 kegiatan pembelajaran tidak dapat berjalan dengan maksimal. Pandemi covid-19 yang tengah melanda berbagai Negara di dunia termasuk Indonesia telah memberikan dampak pada seluruh aspek kehidupan manusia termasuk pada aspek pendidikan (Amiruddin et al., 2021). Upaya yang dilakukan pemerintah untuk menekan penyebaran 
virus kususnya pada bidang pendidikan yakni mengeluarkan kebijakan pembelajaran daring (Anugrahana, 2020; Hasibuan et al., 2020).

Pembelajaran daring (dalam jaringan) merupakan suatu proses pembelajaran yang dilakukan dengan memanfaatkan berbagai platform digital serta menggunakan jaringan internet dalam proses pelaksanaannya (Astini, 2020; Salsabila et al., 2020). Pembelajaran secara daring memungkinkan guru dan siswa untuk belajar dalam waktu yang bersamaan pada tempat yang berbeda (Ghasya et al., 2021). Pelaksanaan pembelajaran daring di Indonesia merupakan suatu bentuk terobosan baru dalam bidang pendidikan, dimana proses pembelajaran secara daring akan dapat meningkatkan kemampuan guru dan siswa untuk memanfaatkan teknologi dalam kegiatan belajar mengajar. Kondisi pembelajaran daring sesungguhnya menuntut siswa untuk dapat belajar secara mandiri dengan memfokuskan pada kesiapan dan ketelitian siswa dalam mengolah dan menerima pembelajaran yang disajikan secara online oleh guru (D. R. Hidayat et al., 2020; Susanty, 2020). Sehingga melalui pembelajaran daring siswa akan mampu meningkatkan kemampuan penggunaan teknologi serta belajar secara aktif dan kreatif untuk merekonstruksi pengetahuannya sendiri (Santika, 2020; Wairata, 2021).

Hanya saja pada proses pelaksanaannya, pembelajaran daring tidak dapat berjalan dengan maksimal. Hal ini tidak terlepas dari kebijakan pelaksanaan pembelajaran daring yang terkesan mendadak sehingga tidak semua komponen pendidikan siap untuk merima hal tersebut (Dewi et al., 2021). Terdapat berbagai macam kendala yang dialami oleh siswa saat pelaksanaannya pembelajaran, seperti kurangnya tingkat pemahaman materi, tidak adanya fasilitas pembelajaran yang memadai, motivasi belajar rendah, serta menurunnya hasil belajar siswa (Sartika, 2021; Widikasih et al., 2021; Widodo \& Nursaptin, 2020; Yuangga \& Sunarsi, 2020). Permasalahan-permasalahan yang dialami oleh siswa selama proses pembelajaran daring, jika dibiarkan terus menerus akan berdampak pada penurunan kualitas pendidikan serta tidak tercapainya tujuan pembelajaran. Sehingga untuk mengatasi hal tersebut guru sebagai tenaga pendidik dituntut untuk mampu menciptakan proses pembelajaran yang bermakna bagi siswa.

Salah satu upaya yang dapat dilakukan yakni dengan merancang sebuah lembar kerja peserta didik (LKPD). LKPD merupakan kumpulan dari lembaran yang berisi materi berdasarkan kompetensi dasar (KD), ringkasan, dan kegiatan yang akan dilakukan peserta didik (Pranowo et al., 2021; Rizalini \& Sofyan, 2018; Satura et al., 2021). Dalam LKPD juga disajikan informasi mengenai interaksi dari guru kepada siswa agar siswa dapat mengerjakan sendiri suatu aktifitas belajar, melalui praktek atau penerapan hasil-hasil belajar untuk mencapai tujuan intruksional (perintah) (Hamidah et al., 2018; Lestari et al., 2018). LKPD dapat berfungsi sebagai penuntun siswa untuk menemukan konsep yang dipelajari, sehinggga pembelajaran bersifat konstruktivis (Noprinda \& Soleh, 2019). Penggunaan LKPD dalam kegiatan pembelajaran akan dapat mengaktifkan siswa, memungkinkan siswa dapat belajar sendiri menurut kemampuan dan minatnya, merangsang kegiatan belajar serta memberikan variasi terhadap kegiatan pembelajaran sehingga siswa tidak mudah bosan (Eliati, 2020).

Penggunaan LKPD akan lebih maksimal apabila disertai dengan penggunaan pendekatan pembelajaran. Salah satu pendekatan yang sesuai dengan penggunaan LKPD yakni pendekatan CTL (Contextual Teaching and Learning) atau biasa disebut dengan pendekatan konstektual. Pendekatan CTL merupakan suatu pendekatan pembelajaran yang mengkaitkan materi ajar dengan berbagi fenomena yang terjadi di lingkungan (P. W. Hidayat \& Widjajanti, 2018; Ramdani, 2018). Pendekatan CTL adalah konsep belajar yang membantu guru mengkaitkan antara materi pembelajaran yang diajarkan dengan situasi dunia nyata siswa dan mendorong siswa membuat hubungan antara pengetahuan yang dimilkinya dengan penerapanya dalam kehidupan mereka sehari-hari (Chityadewi, 2019; Muga et al., 2019). Melalui pendekatan CTL siswa akan belajar untuk memahami makna materi pelajaran yang dipelajarinya dengan mengkaitkan materi tersebut dengan konteks kehidupan mereka sehari-hari sehingga siswa memilki pengetahuan atau ketrampilan yang secara refleksi dapat diterapkan dari permasalahan kepermasalan lainya (Ariani \& Yolanda, 2019; Firmansyah et al., 2018; Karim, 2017).

LKPD yang dikembangkan dengan menggunakan model CTL akan mengaitkan berbagai materi ajar dengan kehidupan sehari-hari sehingga siswa akan lebih mudah memahami dan lebih mudah menemukan berbagai solusi atas permasalahan atau fenomena yang disajikan dalam LKPD. Beberapa penelitian yang telah dilakukan sebelumnya menyebutkan bahwa tingkat validasi lembar kerja peserta didik berbasis pendekatan contextual teaching learning untuk membangun kemampuan berpikir kritis peserta didik pada tema global warming dilihat dari secara keseluruhan termasuk kedalam kategori sangat valid sehingga sangat layak untuk dikembangkan (Romlah et al., 2021). Penelitian lainnya juga menyebutkan bahwa LKPD berbasis Contextual Teaching and Learning dapat digunakan untuk melatihkan keterampilan berpikir kritis siswa, sehingga mampu meningkatkan hasil belajar siswa (Ningrum \& Winarsih, 2020). Penelitian selanjutnya juga menyebutkan bahwa Lembar Kerja Peserta Didik (LKPD) Berbasis Kontekstual yang dikembangkan valid dan dapat digunakan dalam pembelajaran di kelas IV 
Sekolah Dasar (Nareswari et al., 2021). Berdasarkan beberapa penelitian tersebut dapat dikatakan bahwa media LKPD berbasis pendekatan CTL merupakan media yang layak untuk dikembangkan dan dibelajarkan kepada peserta didik karena mampu meningkatkan kemampuan berpikir kritis serta mampu meningkatkan hasil belajar siswa. Hanya saja pada penelitian sebelumnya belum terdapat penelitian yang mengembangkan LKPD berbasis pendekatan CTL pada materi pengembangan teks hasil observasi untuk siswa SMA, sehingga penelitian ini difokuskan pada hal tersebut dengan tujuan untuk mengembangkan Lembar Kerja Peserta Didik (LKPD) berbasis pendekatan Contextual Teaching and Learning (CTL) pada materi teks hasil laporan observasi kelas X SMA.

\section{METODE}

Penelitian ini berbentuk penelitian dan pengembangan (Researh and Development), yang dikembangkan menggunakan model pengembangan ADDIE. Model pengembangan ADDIE terdiri dari 5 tahap yaitu analisis (analysis), desain (design), pengembangan (development), pelaksanaan (implementation), dan evaluasi (evaluation). Tahap analisis (analysis) merupakan tahap awal perencanaan, yaitu pemikiran tentang produk baru yang akan dikembangkan. Tujuan dari tahap analisis ini yaitu untuk mengidentifikasi kemungkinan penyebab kesenjangan yang terjadi. Pada tahap ini terdapat beberapa hal yang perlu diperhatikan dalam proses pengembangan yaitu analisis kurikulum, memvalidasi kesenjangan kinerja, menetapkan tujuan, analisis kebutuhan dan karakteristik siswa, analisis sumber daya yang tersedia, dan rencana kerja. Selanjutnya pada tahap desain (design) dilakukan perancangan dengan tujuan untuk memverifikasi kinerja yang diinginkan dan metode pengujian yang tepat. Pengembangan LKPD ini dilakukan melalui beberapa tahap, yaitu: Rancangan LKPD berbasis Pendekatan CTL, validasi desain (ahli materi dan ahli desain).

Tahap ketiga yakni tahap pengembangan (development), dimana pada tahap ini terdapat beberapa hal yang dikembangkan yaitu isi dari LKPD ini disesuaikan dengan materi dan tujuan pembelajaran yaitu uji coba perorangan, uji coba kelompok kecil, dan uji coba kelompok besar. Tahap keempat yakni tahap pelaksanaan (implementation) produk yang telah diujicoba diterapkan pada situasi nyata dengan pengajaran yang sesungguhnya. Pada penelitian ini tidak dilakukan tahap implementasi sebab tahap implementasi adalah tahap dimana LKPD berbasis pendekatan CTL yang telah dikembangkan diujikan pada seluruh peserta didik kelas X di SMA Swasta Islam Terpadu Trio Batanghari dan pada seluruh materi yang dipelajari dikelas X, sedangkan pada penelitian ini hanya dilakukan terhadap satu kelas dan satu materi pelajaran yakni materi teks hasil laporan observasi. Tahap akhir penelitian yakni tahap evaluasi (evaluation), yang dilakukan dengan tujuan untuk menilai kualitas dari produk dan proses. Tahap evaluasi dilakukan beberapa tahap yaitu evaluasi yang dilakukan ahli media dan ahli materi melalui proses validasi produk, kemudian merevisi produk berdasarkan penilaian dan saran dari ahli desain pembelajaran dan media dan ahli materi serta hasil dari ujicoba produk dan validasi yang telah dilakukan dalam kelompok kecil sebanyak 8 orang siswa. Selanjutnya diujicobakan pada kelompok besar sebanyak 22 orang siswa.

Subjek yang terlibat pada penelitian pengembangan ini adalah dua orang validator yang terdiri dari validator uji ahli materi dan validator uji ahli desain, dan juga sasaran pemakai dari produk ini adalah siswa kelas X SMA. Pada penilaian validasi ahli materi dilakukan oleh dosen program studi pendidikan bahasa indonesia Universitas Jambi yang merupakan seorang yang ahli dan berpengalaman sehingga penilaiannya terhadap media pembelajaran pada materi teks hasil laporan observasi ini dapat membuat produk ini menjadi lebih baik. Jenis data yang diambil dalam penelitian ini berupa data kualitatif dan data kuantitatif. Data kualitatif diperoleh dari hasil validator ahli materi dan ahli desain, tanggapan dari guru bidang studi bahasa indonesia, dan hasil angket tanggapan siswa terhadap media pembelajaran yang telah dibuat, sedangkan kuantitatif diperoleh dari hasil belajar siswa melalui post-test (tes akhir). Teknik analisis data penelitian ini dilakukan dengan menggunakan statistik deskriptif. Analisis meliputi analisis validasi instrumen penelitian dan LKPD, serta efektivitas LKPD.

\section{HASIL DAN PEMBAHASAN}

Hasil

Hasil dari penelitian pengembangan ini yakni berupa sebuah Lembar Kerja Siswa (LKPD) berbasis pendekatan Contextual Teaching and Learning (CTL) pada materi teks hasil laporan observasi untuk meningkatkan hasil belajar siswa, penilaian isi materi dan desain LKPD oleh ahli materi dan ahli desain LKPD, penilaian siswa terhadap LKPD yang telah dibuat, Respon siswa terhadap penggunaan LKPD berbasis pendekatan CTL pada materi teks hasil laporan observasi yang didapat dari angket yang telah divalidasi oleh ahli instrumen, serta hasil belajar siswa terhadap penggunaan LKPD berbasis pendekatan 
CTL pada materi teks hasil laporan observasi dengan memberikan post-test kepada siswa kelas X SMA IT Trio Batanghari. Hasil penelitian dianalisis berdasarkan pada tahap-tahap pengembangan media melalui model ADDIE. Tahapan pengembangan yang pertama yakni tahap analyze. Pada tahap analyze dilakukan analisis kurikulum, analisis proses belajar, analisis karakteristik, serta analisis kebutuhan belajar siswa. Hasil analisis kurikulum menunjukkan bahwa kurikulum yang digunakan oleh siswa SMA Islam Terpadu Trio Batanghari adalah kurikulum K13. Pada hasil analisis proses pembelajaran didapatkan hasil bahwa proses pembelajaran siswa cenderung hanya dilakukan dengan metode ceramah dan hanya berfokus pada penggunaan buku paket. Selanjutnya pada analisis kebutuhan dan karekteristik siswa diperoleh hasil bahwa siswa pada jenjang SMA cenderung memiliki karakteristik yang mudah bosan, sehingga sulit fokus pada proses pembelajaran yang hanya terkesan menoton. Siswa yang cenderung cepat bosan membutuhkan media pembelajaran yang mampu menarik perhatian dan peran aktif siswa.

Setelah dilakukan analisis terhadap kurikulum, karakteristik, serta kebutuhan siswa maka penelitian dilanjutkan pada tahap design atau perancangan media. Pada tahap ini dilakukan proses pembuatan flowchart, storyboard, serta LKPD berbasis pendekatan CTL. Tahap penelitian ketiga yakni tahap development atau pengembangan. Pada tahap ini dilakukan pengembangan media sesuai dengan rancangan yang telah disusun sebelumnya. LKPD yang telah dibuat kemudian diuji validitas isi materinya oleh Bapak Dr. Herman Budiono M.Pd dengan mengisi angket yang terdiri dari 4 indikator dengan 13 pertanyaan menunjukkan bahwa materi yang terdapat pada LKPD sesuai dengan tujuan pembelajaran materi teks hasil laporan observasi, teknik penulisannya baik, penyusunan bahasanya baik dan disejutui untuk langsung digunakan dalam penelitian. Selanjutnya hasil uji validitas desain oleh Ibu Dr. Irma Suryani, M.Pd terhadap LKPD berbasis CTL pada materi teks hasil laporan observasi yang telah dibuat dengan mengisi angket yang terdiri dari 5 indikator dan 14 pertanyaan, menunjukkan bahwa desain pembelajaran yang terdapat pada LKPD sesuai dengan tujuan pembelajaran materi teks hasil laporan observasi, teknik penulisannya baik, penyusunan bahasanya baik dan disejutui untuk langsung digunakan dalam penelitian. Saran yang diterima oleh peneliti berupa saran dalam bentuk tulisan yang disampaikan maupun lisan yang disampaikan oleh ahli materi, ahli desain pembelajaran dan ahli media.

LKPD yang telah direvisi sesuai dengan saran dan komentar tim ahli, maka dilakukan evaluasi formatif untuk melihat efektifitas LKPD. Adapun tahapan dari evaluasi formatif terbagi atas 3 tahap yaitu ujicoba perorangan (one-to-one trial), ujicoba kelompok kecil (small group trial), dan ujicoba kelompok besar (field tryout). Ujicoba perorangan dilakukan peneliti dengan subjek uji coba salah seorang guru bahasa indonesia kelas X yaitu Ibu Desi Puji Rahayu, S.Pd yang akan menilai LKPD yang dibuat penulis secara keseluruhan sesuai dengan silabus dan kebutuhan siswa. Komentar dan saran dari uji coba praktisi adalah media pembelajaran yaitu LKPD yang didesain dengan menggunakan konteks dunia nyata didalamnya sangat membantu siswa dalam proses pembelajaran dan dapat diujicobakan dilapangan. Karena siswa menemukan hal-hal baru yang belum ditemukan siswa pada LKPD sebelumnya. Hasil yang diperoleh pada uji coba perorangan mendapatkan respon yang sangat positif sehingga dinyatakan layak untuk digunakan ketahap selanjutnya pada uji coba kelompok kecil.

Pada tahap uji coba kelompok kecil merupakan non subjek uji coba penelitian, siswa yang dipilih sebanyak 8 orang dari kelas X SMAS IT Trio Batanghari dimana siswa ini berkemampuan rendah, sedang, dan tinggi. Pemilihan siswa yang menjadi subjek uji coba kelompok kecil ini dibantu oleh guru bahasa indonesia yang mengajar di kelas tersebut yang telah mengetahui kemampuan siswa dikelas X. Dalam uji coba kelompok kecil peneliti hanya sebagai observator. Uji coba ini dilakukan dengan maksud memberikan masukan kepada peneliti terhadap LKPD yang akan dikembangkan. Hasil evaluasi uji coba kelompok kecil tersebut digunakan untuk merevisi LKPD yang telah dibuat dengan mengarahkan siswa untuk mengamati keseluruhan LKPD, dan kemudian mengisi angket tanggapan yang telah diberikan. Pada uji coba kelompok kecil juga diadakan pre-test dan post-test. Hasil pre-test dan post-test menunjukkan bahwa nilai siswa sebelum menggunakan LKPD yakni $s<55$ sedangkan nilai siswa setelah menggunakan LKPD menjadi bervariasi dengan nilai mencapai 72. Skor gain didapat mencapai nilai 0,7 dan berada pada kriteria tinggi untuk peningkatan hasil belajar siswa.

Selanjutnya pada Ujicoba kelompok besar dilibatkan 22 subjek penelitian yaitu siswa kelas X SMAS IT Trio Batanghari. Kegiatan pembelajaran dilaksanakan dengan mengarahkan siswa untuk mengamati keseluruhan LKPD. Setelah pelaksanaan proses pembelajaran selesai masing-masing siswa diberikan angket untuk menilai aspek pada LKPD secara keseluruhan dan melihat tanggapan siswa terhadap penggunaan LKPD berbasis pendekatan CTL pada materi teks hasil laporan observasi. Sebelum siswa mengisi angket, ssiswa diberikan penjelasan mengenai cara pengisian dan poin pada masing-masing angket. Hasil rekapitulasi tanggapan siswa pada ujicoba kelompok besar menunjukkan hasil yang positif. Karena tanggapan siswa pada uji coba kelompok besar ini positif maka LKPD dapat digunakan ke tahap selanjutnya pada tahap implementasi tanpa revisi. Pada uji coba kelompok besar juga diadakan pre-test dan post-test. Hasil pre-test dan post-test menunjukkan bahwa nilai siswa sebelum menggunakan LKPD 
yakni < 55 sedangkan nilai siswa setelah menggunakan LKPD menjadi bervariasi dengan nilai mencapai 78. Untuk uji gain melihat peningkatan hasil belajar siswa. Skor gain didapat 0,8 berada pada kriteria tinggi untuk peningkatan hasil belajar siswa.

Pada tahap implementation produk yang telah diujicoba diterapkan dalam situasi nyata dengan pengajaran yang sesungguhnya menggunakan LKPD berbasis pendekatan CTL pada materi teks hasil laporan observasi yang melibatkan subjek 30 siswa atau satu kelas yaitu kelas X SMAS IT Trio Batanghari. Kegiatan pembelajaran dilaksanakan selama 3 kali pertemuan. Pada tahapan implementasi juga dilakukan pre-test dan post-test bertujuan untuk melihat peningkatan hasil belajar siswa. Hasil pre-test dan post-test menunjukkan bahwa nilai siswa sebelum menggunakan LKPD berada < 55 sedangkan nilai siswa setelah menggunakan LKPD menjadi bervariasi dengan nilai mencapai 86. Untuk uji gain melihat peningkatan hasil belajar siswa terlihat skor gain didapat 0,7 berada pada kriteria tinggi untuk peningkatan hasil belajar siswa. Kegiatan akhir peneliti dan siswa melakukan refleksi dengan melakukan tanya jawab untuk memperkuat skema yang didapat oleh siswa. Peneliti juga meminta siswa untuk menyampaikan apa saja yang mereka dapatkan dan mampu mereka kuasai selama proses pembelajaran pada materi teks hasil laporan observasi. Terakhir peneliti menutup pembelajaran dan meminta siswa mengerjakan post-test serta memberikan angket persepsi siswa pada siswa. Angket yang digunakan merupakan angket tertutup yang digunakan untuk menilai aspek pada LKPD secara keseluruhan. Diperoleh bahwa respon sangat baik didapatkan dari semua pertanyaan angket persepsi. Dari data tersebut dapat disimpulkan bahwa LKPD berbasis pendekatan CTL dipersepsikan sangat baik oleh siswa. Rata-rata setiap pertanyaan angket memiliki skor persentase $>80 \%$ yang dinyatakan sangat baik, untuk skor persentase keseluruhan yaitu 95\% yang artinya persepsi siswa sangat baik terhadap LKPD.

Evaluasi yang dimaksudkan untuk memperbaiki LKPD di setiap tahapnya, evaluasi ini disebut evaluasi formatif. Sehingga diperoleh sebuah LKPD yang layak untuk digunakan pada proses pembelajaran. Adapun evaluasi yang secara umum adalah melihat persepsi, pengetahuan dan sikap, evaluasi ini juga disebut evaluasi sumatif. Namun pada penelitian ini hanya sampai melihat pengetahuan. Dari evaluasi ini akan diperoleh hasil berupa LKPD yang dikatakan efektif bila media dipersepsikan secara positif oleh siswa dan tujuan dari pengembangan LKPD ini tercapai yaitu meningkatnya hasil belajar siswa untuk materi teks hasil laporan observasi. Berdasarkan evaluasi yang dilakukan didapat LKPD berbasis pendekatan CTL yang valid menurut tim ahli validator, ditanggapi dengan tanggapan positif oleh guru mata pelajaran bahasa indonesia SMAS IT Trio Batanghari, dinilai dengan tanggapan yang positif oleh siswa pada ujicoba produk LKPD sehingga LKPD tidak mengalami revisi untuk tahapan implementasi. Pada tahapan implementasi didapat hasil persepsi siswa sangat baik terhadap LKPD yang dikembangkan, dan hasil belajar siswa mengalami peningkatan. Berdasarkan hasil yang didapat, dapat disimpulkan bahwa LKPD berbasis pendekatan CTL efektif terhadap pembelajaran pada materi teks hasil laporan observasi. Adapun produk Produk LKPD berbasis problem based learning yang dihasilkan dalam penelitian ini dapat dilihat pada gambar 1,2 , dan 3 .

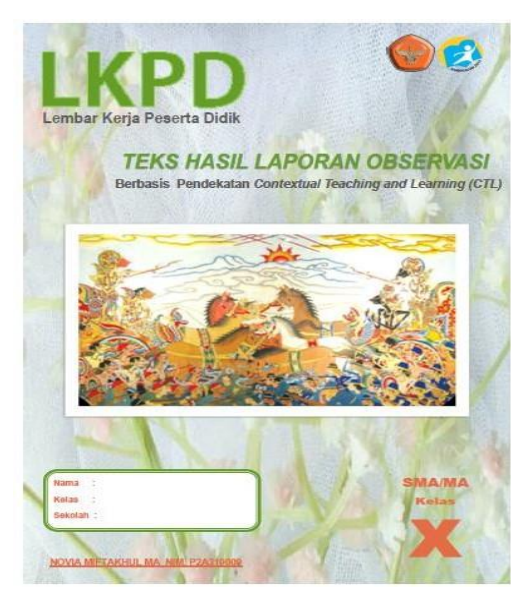

Gambar 1. Halaman Sampul

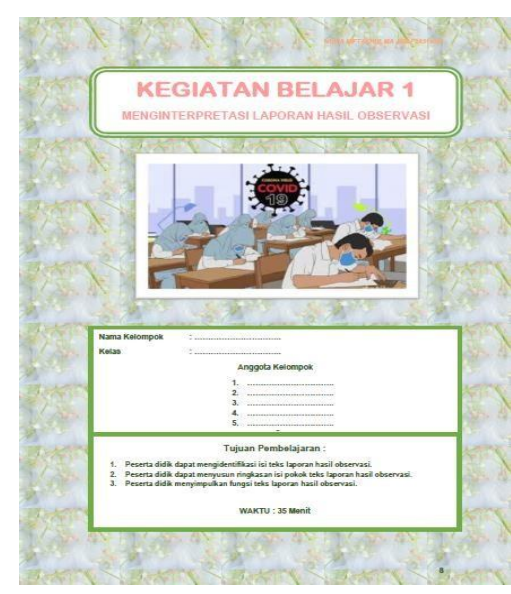

Gambar 2. Halaman Kegiatan Belajar 1

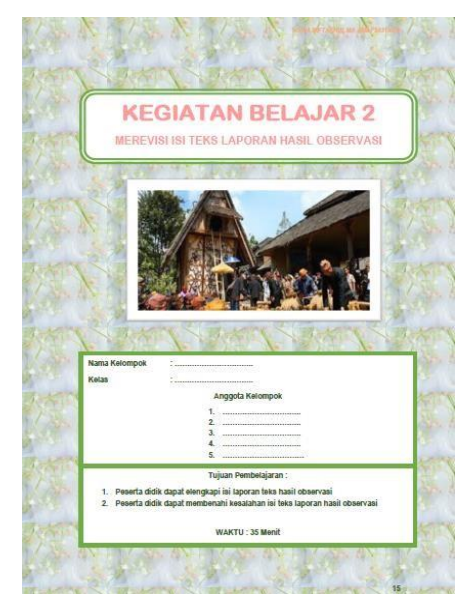

Gambar 3. Halaman Kegiatan Belajar 2

\section{Pembahasan}

Media LKPD berbasis pendekatan CTL yang dikembangkan menggunakan model pengembangan ADDIE, mendapatkan hasil penilaian yang sangat baik oleh para ahli. Hal ini dikarenakan LKPD berbasis model CTL yang dikembangkan menyajikan materi sesuai dengan kebutuhan siswa, menggunakan bahasa 
yang mudah dipahami, serta memiliki desain yang menarik. Materi yang disajikan pada LKPD adalah materi mengenai penyajian teks hasil observasi. Penyajian materi serta gambar-gambar pendukung telah disesuaikan dengan SK, KD, Indikator, serta tujuan pembelajaran yang hendak dicapai. Kesesuain antara LKPD dengan SK, KD, Indikator, serta tujuan pembelajaran merupakan salah satu komponen penting yang mendukung keberhasilan suatu pengembangan media (Nurbaiti, 2019; Syahrudin et al., 2019). Media yang telah disesuaikan dengan kebutuhan materi serta karakteristik siswa akan mempermudah proses belajar sehingga tujuan belajar siswa akan tercapai dan proses pembelajaran akan berlangsung lebih efektif (Geni et al., 2020; Putri et al., 2020). Selain ditentukan oleh isi materi, keberhasilan pengembangan LKPD juga dipengaruhi oleh desain LKPD itu sendiri. LKPD yang didesain semenarik mungkin tentu akan menarik minat siswa untuk membaca dan memahaminya lebih lanjut. Kesesuaian warna latar, tulisan, serta gambar akan memberikan kesan nyaman kepada siswa saat membaca dan mengerjakan LKPD tersebut.

LKPD yang dikembangkan dengan memperhatikan kebutuhan serta karakteristik siswa akan mendapat kesan positif dari siswa serta dapat meningkatkan hasil belajar siswa (Firdaus \& Wilujeng, 2018; Makhrus et al., 2018). Kesan positif yang diberikan siswa pada LKPD yang dikembangkan menunjukkan bahwa siswa tersebut menyukai LKPD yang dikembangkan (Wahyuni et al., 2021). Jika siswa telah menyukai LKPD tersebut tentu siswa akan merasa nyaman dan lebih mudah memahami materi yang disajikan didalamnya. Selain mendapat respon positif dari siswa LKPD berbasis pendekatan CTL ini juga mampu meningkatkan hasil belajar siswa. Hasil belajar pada umumnya merupakan salah satu acuan terhadap keberhasilan dalam proses pendidikan, yang ditunjukkan dengan adanya perkembangan kemampuan siswa (Mahesti \& Koeswanti, 2021; Nurrita, 2018; Pradilasari et al., 2019; Saputra et al., 2018). Peningkatan hasil belajar siswa melalui penggunaan LKPD berbasis pendekatan CTL tidak terlepas dari karakteristik LKPD itu sendiri. Dimana LKPD memiliki karakteristik memuat informasi mengenai interaksi dari guru kepada siswa agar siswa dapat mengerjakan sendiri suatu aktifitas belajar, melalui praktek atau penerapan hasil-hasil belajar untuk mencapai tujuan intruksional (perintah), sehingga melalui LKPD proses belajar siswa menjadi lebih tersturktur dan terarah (Firdaus \& Wilujeng, 2018; Purnama \& Suparman, 2020). Selain dipengaruhi oleh penggunaan LKPD, peningkatan hasil lbelajar juga dipengaruhi oleh pendekatan CTL. Pendekatan CTL memungkinkan siswa untuk belajar memahami makna materi pelajaran yang dipelajarinya dengan mengkaitkan materi tersebut dengan konteks kehidupan mereka sehari-hari sehingga siswa memilki pengetahuan atau ketrampilan yang secara refleksi dapat diterapkan dari permasalahan kepermasalan lainya (Firmansyah et al., 2018; Karim, 2017; Simatupang, 2021). LKPD yang dikembangkan dengan menggunakan model CTL akan mengaitkan berbagai materi ajar dengan kehidupan sehari-hari sehingga siswa akan lebih mudah memahami dan lebih mudah menemukan berbagai solusi atas permasalahan atau fenomena yang disajikan dalam LKPD.

Hasil yang diperoleh pada penelitian ini sejalan dengan beberapa hasil penelitian sebelumnya, yang juga menyebutkan bahwa tingkat validasi lembar kerja peserta didik berbasis pendekatan contextual teaching learning untuk membangun kemampuan berpikir kritis peserta didik pada tema global warming dilihat dari secara keseluruhan termasuk kedalam kategori sangat valid sehingga sangat layak untuk dikembangkan (Romlah et al., 2021). Penelitian lainnya juga menyebutkan bahwa LKPD berbasis Contextual Teaching and Learning dapat digunakan untuk melatihkan keterampilan berpikir kritis siswa, sehingga mampu meningkatkan hasil belajar siswa (Ningrum \& Winarsih, 2020). Penelitian selanjutnya juga menyebutkan bahwa Lembar Kerja Peserta Didik (LKPD) Berbasis Kontekstual yang dikembangkan valid dan dapat digunakan dalam pembelajaran di kelas IV Sekolah Dasar (Nareswari et al., 2021). Sehingga berdasarkan hal tersebut diketahui bahwa media LKPD berbasis CTL merupakan media yang efektif san sangat cocok untuk dibelajarkan kepada siswa

\section{SIMPULAN}

LKPD berbasis pendekatan CTL yang dikembangkan dengan menggunakan model pengembangan ADDIE memiliki nilai validitas sangat tinggi. Selain itu LKPD berbasis pendekatan CTL ini juga mendapat respon positif dari siswa karena secara signifikan mampu meningkatkan hasil belajar siswa kususnya pada materi penyajian teks hasil observasi.

\section{DAFTAR PUSTAKA}

Amiruddin, A., Rubianti, I., Azmin, N., Nasir, M., \& Sandi, A. (2021). Analisis Penerapan Kurikulum 2013 Dalam Meningkatkan Kualitas Pembelajaran Masa Pandemik Covid-19 di SMAN 3 Kota Bima. Jurnal Ilmiah Pendidikan, Sosial, Dan Politik, 7(4). https://doi.org/10.36312/jime.v7i4.2398.

Anugrahana, A. (2020). Hambatan, Solusi dan Harapan: Pembelajaran Daring Selama Masa Pandemi Covid-19 Oleh Guru Sekolah Dasar. Scholaria: Jurnal Pendidikan Dan Kebudayaan, 10(3), 282-289. 
https://doi.org/10.24246/j.js.2020.v10.i3.p282-289.

Ariani, T., \& Yolanda, Y. (2019). Effectiveness of Physics Teaching Material Based on Contextual Static Fluid Material. Kasuari: Physics Education Journal (KPEJ), 2(2), 70-81. https://doi.org/10.37891/kpej.v2i2.99.

Astini, N. K. suni. (2020). Tantangan Dan Peluang Pemanfaatan Teknologi Informasi Dalam Pembelajaran Online Masa Covid-19. Cetta: Jurnal Ilmu Pendidikan, 3(2), 241-255. https://doi.org/10.37329/cetta.v3i2.452.

Chityadewi, K. (2019). Meningkatkan Hasil Belajar Matematika Pada Materi Operasi Hitung Penjumlahan Pecahan Dengan Pendekatan Ctl (Contextual Teaching And Learning). Journal of Education Technology, 3(3), 196. https://doi.org/10.23887/ jet.v3i3.21746.

Dewi, T., Masruhim, M. A., \& Sulistiarini, R. (2021). Problematika Dan Solusi Alternatif Pembelajaran Daring Untuk Mata Pelajaran Matematika Di Sekolah Dasar Negeri 13/Iv Kota Jambi. Jurnal Pendidikan Tematik, 6(1), 5-24. https://online-journal.unja.ac.id/JPTD/article/view/13679.

Eliati, T. A. (2020). Pengembangan LKPD berbasis Masalah (PBL) untuk meningkatkan self-efficacy peserta didik. Hipotenusa Journal of Research Mathematics Education (HJRME), 3(1), 19-31. https://doi.org/10.36269/hjrme.v3i1.148.

Firdaus, M., \& Wilujeng, I. (2018). Pengembangan LKPD inkuiri terbimbing untuk meningkatkan keterampilan berpikir kritis dan hasil belajar peserta didik. Jurnal Inovasi Pendidikan IPA, 4(1), 26-40. https://doi.org/10.21831/jipi.v4i1.5574.

Firmansyah, A., Hasanuddin, H., \& Nelson, Z. (2018). Pengaruh Model Pembelajaran Contextual Teaching and Learning terhadap Kemampuan Komunikasi Matematis Berdasarkan Pengetahuan Awal Siswa. JURING (Journal for Research in Mathematics Learning), 1(1), 01. https://doi.org/10.24014/juring.v1i1.4772.

Geni, K. H. Y. W., Sudarma, I. K., \& Mahadewi, L. P. P. (2020). Pengembangan Multimedia Pembelajaran Interaktif Berpendekatan CTL Pada Pembelajaran Tematik Siswa Kelas IV SD. Jurnal Edutech Undiksha, 8(2), 1. https://doi.org/10.23887 /jeu.v8i2.28919.

Ghasya, D. A. V., Salimi, A., \& Pranata, R. (2021). Analisis Keterlaksanaan Pembelajaran Jarak Jauh Mata Pelajaran Matematika Di Kelas Tinggi Sekolah Dasar Pada Masa Pandemi Covid-19. Numeracy, 8(1), 41-57. https://doi.org/10.46244/numeracy.v8i1. 1424.

Hamidah, N., Sri, H., \& Sri, W. (2018). Efektivitas Lembar Kerja Peserta Didik Berbasis Inkuiri Terbimbing untuk Meningkatkan Hasil Belajar Siswa. Jurnal Inovasi Pendidikan Kimia, 12(2), 2212-2223. https://journal.unnes.ac.id/nju/index.php/JIPK /article/view/7460.

Hasibuan, M. T. D., Mendrofa, H. K., Silaen, H., \& Tarihoran, Y. (2020). Hubungan Motivasi Belajar Terhadap Prestasi Akademik Pada Mahasiswa Yang Menjalani Pembelajaran Daring Selama Pandemi Covid19. Indonesian Trust Health Journal, 3(2), 387-393. https://doi.org/10.37104/ithj.v3i2.65.

Hidayat, D. R., Rohaya, A., Nadine, F., \& Ramadhan, H. (2020). Kemandirian Belajar Peserta Didik Dalam Pembelajaran Daring Pada Masa Pandemi Covid -19. Perspektif Ilmu Pendidikan, 34(2), 147-154. https://doi.org/10.21009/PIP.342.9.

Hidayat, P. W., \& Widjajanti, D. B. (2018). Analisis kemampuan berpikir kreatif dan minat belajar siswa dalam mengerjakan soal open ended dengan pendekatan CTL. Pythagoras: Jurnal Pendidikan Matematika, 13(1), 63-75. https://doi.org/10.21831 /pg.v13i1.21167.

Izma, T., \& Kesuma, V. Y. (2019). Peran Pendidikan Kewarganegaraan Dalam Membangun Karakter Bangsa. Wahana Didaktika: Jurnal Ilmu Kependidikan, 17(1), 84. https://doi.org/10.31851/wahanadidaktika.v17i1.2419.

Karim, A. (2017). Analisis Pendekatan Pembelajaran CTL (Contextual Teaching And Learning) Di SMPN 2 Teluk Jambe Timur, Karawang. Formatif: Jurnal Ilmiah Pendidikan MIPA, 7(2). https://doi.org/10.30998/formatif.v7i2.1578.

Lestari, L., Alberida, H., \& Rahmi, Y. L. (2018). Validitas dan Praktikalitas Lembar Kerja Peserta Didik (LKPD) Materi Kingdom Plantae Berbasis Pendekatan Saintifik untuk Peserta Didik Kelas X SMA/MA. Jurnal Eksakta Pendidikan (JEP), 2(2), 170. https://doi.org/10.24036/jep/vol2iss $2 / 245$.

Mahesti, G., \& Koeswanti, H. D. (2021). Pengembangan Media Pembelajaran Permainan Monopoli Asean untuk Meningkatkan Hasil Belajar Tema 1 Selamatkan Makhluk Hidup Pada Siswa Kelas 6 Sekolah Dasar. Mimbar PGSD, 9(1). https://doi.org/ 10.23887/jjpgsd.v9i1.33586.

Makhrus, M., Harjono, A., Syukur, A. B., \& Muntari, S. (2018). Identifikasi kesiapan LKPD guru terhadap keterampilan abad 21 pada pembelajaran IPA SMP. Jurnal Ilmiah Profei Pendidikan, 3(2), 124128. https://doi.org/10.29303/jipp.v3i2.20.

Muga, W., Oje, M. S., \& Laksana, D. N. L. (2019). Hasil Belajar Kognitif Siswa Sd Dalam Pembelajaran Kontekstual Media Mazi (Studi Pada Siswa Sd Kelas Tinggi). Journal of Education Technology, 2(1), 
20. https://doi.org/10.23887/jet.v2i1.13802.

Nareswari, N. L. P. S. R., Suarjana, I. M., \& Sumantri, M. (2021). Belajar Matematika dengan LKPD Berbasis Kontekstual. Mimbar Ilmu, 26(2), 204. https://doi.org/10. 23887/mi.v26i2.35691.

Ningrum, S. N. K., \& Winarsih. (2020). Pengembangan Lembar Kegiatan Peserta Didik Berbasis Contextual Teaching And Learning Pada Sub-Materi Interaksi Antar Komponen Ekosistem. Jurnal Berkala Ilmiah Pendidikan Biologi, 9(3), 406-413. https://ejournal.unesa.ac.id/index.php/bioedu/article/view/36767.

Noprinda, C. T., \& Soleh, S. M. (2019). Pengembangan Lembar Kerja Peserta Didik (LKPD) Berbasis Higher Order Thinking Skill (HOTS). Indonesian Journal of Science and Mathematics Education, 2(2), 168176. https://doi.org/10.24042/ ijsme.v2i2.4342.

Nurbaiti. (2019). Pengembangan Lembar Kerja Siswa Berbasis Open Ended Problem Pada Materi Pecahan Untuk Siswa Sekolah Dasar. Jurnal Education and Development, $7(3)$. https://doi.org/10.37081/ed.v7i3.1215.

Nurrita, T. (2018). Pengembangan Media Pembelajaran Untuk Meningkatkan Hasil Belajar Siswa. Misykat: Jurnal Ilmu-Ilmu Al-Quran, Hadist, Syari'ah Dan Tarbiyah, 3(1), 171. https://doi.org/10.33511/misykat.v3n1.171.

Pane, A., \& Dasopang, M. D. (2017). Belajar Dan Pembelajaran. Fitrah:Jurnal Kajian Ilmu-Ilmu Keislaman, 3(2), 333. https://doi.org/10.24952/ fitrah.v3i2.945.

Pradilasari, L., Gani, A., \& Khaldun, I. (2019). Pengembangan Media Pembelajaran Berbasis Audio Visual pada Materi Koloid Untuk Meningkatkan Motivasi dan Hasil Belajar Siswa SMA. 07(01), 9-15. https://doi.org/10.24815/jpsi.v7i1.13293.

Pranowo, M. I., Linda, R., \& Haryati, S. (2021). Pengembangan LKPD Kimia Berbasis Science, Environment, Technology, and Society (SETS) Materi Laju Reaksi. JRPK: Jurnal Riset Pendidikan Kimia, 11(1), 4145. https://doi.org/10.21009/JRPK.111.07.

Purnama, A., \& Suparman, S. (2020). Studi Pendahuluan: E-LKPD Berbasis PBL untuk Meningkatkan Kemampuan Literasi Matematis Peserta Didik. JKPM (Jurnal Kajian Pendidikan Matematika), 6(1), 131. https://doi.org/10.30998/jkpm.v6i1.8169.

Putri, A., Kuswandi, D., \& Susilaningsih, S. (2020). Pengembangan Video Edukasi Kartun Animasi Materi Siklus Air untuk Memfasilitasi Siswa Sekolah Dasar. JKTP: Jurnal Kajian Teknologi Pendidikan, 3(4), 377-387. https://doi.org/10.17977/ um038v3i42020p377.

Ramdani, E. (2018). Model Pembelajaran Kontekstual Berbasis Kearifan Lokal sebagai Penguatan Pendidikan Karakter. JUPIIS: Jurnal Pendidikan Ilmu-Ilmu Sosial, 10(1), 1. https://doi.org/10.24114/jupiis.v10i1.8264.

Rizalini, R., \& Sofyan, H. (2018). Pengembangan lembar kerja peserta didik kimia berbasis inkuiri terbimbing untuk kelas Xi IPA SMA/MA. Jurnal Inovasi Teknologi Pendidikan, 5(2), 103-114. https://doi.org/10.21831/jitp.v5i2.14445.

Romlah, S., Hodijah, N., \& Taufik, A. N. (2021). Pengembangan LKPD Berbasis Pendekatan Contextual Teaching Learning untuk Membangun Kemampuan Berpikir Kritis Peserta Didik pada Tema Global Warming. Journal of Science Education, 6(1), 278-284. https://doi.org/10.33369/pendipa.6.1.278-284.

Salsabila, U. H., Sari, L. I., Lathif, K. H., Lestari, A. P., \& Ayuning, A. (2020). Peran Teknologi Dalam Pembelajaran Di Masa Pandemi Covid-19. Al-Mutharahah: Jurnal Penelitian Dan Kajian Sosial Keagamaan, 17(2), 188-198. https://doi.org/10.46781/ al-mutharahah.v17i2.138.

Santika, I. W. E. (2020). Pendidikan Karakter pada Pembelajaran Daring. Evaluation Values and Character Education Journal, 3(1). https://doi.org/10.23887/ivcej.v3i1. 27830.

Saputra, H. D., Ismet, F., \& Andrizal, A. (2018). Pengaruh Motivasi Terhadap Hasil Belajar Siswa SMK. INVOTEK: Jurnal Inovasi Vokasional Dan Teknologi, 18(1), 25-30. https://doi.org/10.24036/invotek.v18i1.168.

Sartika, dewi. (2021). Dampak Pandemi Covid-19 Pada Pembelajaran Daring Di Pendidikan Madrasah Ibtidaiyah Dan Sekolah Dasar Di Kota Bima. Jurnal Kreatif, 19(2). hhttps://doi.org/10.52266/kreatif.v19i1.683.

Satura, Y. T., Abdullah, A., \& Rery, R. U. (2021). Pengembangan LKPD Aplikatif Integratif Berbasis Inquiri Terbimbing Pada Materi Kesetimbangan Kimia. Jurnal Pijar Mipa, 16(1), 64. https://doi.org/10.29303/jpm.v16i1.1647.

Shidiq, A. F., \& Raharjo, S. T. (2018). Peran Pendidikan Karakter Di Masa Remaja Sebagai Pencegahan Kenakalan Remaja. Prosiding Penelitian Dan Pengabdian Kepada Masyarakat, 5(2), 176. https://doi.org/10.24198/jppm.v5i2.18369.

Simatupang, A. (2021). Hubungan Motivasi Belajar Dengan Hasil Belajar Siswa Pada Mata Pelajaran Kimia Di Sma Negeri 2 Kota Jambi. Secondary: Jurnal Inovasi Pendidikan Menengah, 1(3), 199-205. 
https://doi.org/10.51878/secondary.v1i3.346.

Susanty, S. (2020). Inovasi Pembelajaran Daring Dalam Merdeka Belajar. Jurnal Ilmiah Hospitality, 9(2), 157-166. https://doi.org/10.47492/jih.v9i2.289.

Syahrudin, A., Majid, A., Yuliani, L., \& Qomariah, D. N. (2019). Penerapan Konsep Andragogi Oleh Tutor Kesetaraan Paket C Dalam Meningkatkan Motivasi Belajar Pada Warga Belajar. Jendela PLS, 4(1). https://doi.org/10.37058/jpls.v4i1.1597.

Wahyuni, K. S. P., Candiasa, I. M., \& Wibawa, I. M. C. (2021). Pengembangan E-LKPD Berbasis Kemampuan Berpikir Tingkat Tinggi Mata Pelajaran Tematik Kelas IV Sekolah Dasar. Pendasi: Jurnal Pendidikan Dasar Indonesia, 5(2), 301-311. https://doi.org/10.23887/jurnal_pendas.v5i2.476.

Wairata, E. (2021). Optimalisasi Penerapan Metode Belajar Inkuiri Untuk Meningkatkan Hasil Belajar Pkn Materi Pokok Nilai-Nilai Pancasila Dalam Kerangka Praktik Penyelenggaraan Pemerintahan Negara. Journal of Education Action Research, 5(3). https://doi.org/10.23887/jear.v5i3.35132.

Widikasih, P. A., Widiana, I. W., \& Margunayasa, I. G. (2021). Online Learning Problems for Elementary School Students. Jurnal of Education Reserch and Evaluation, 5(3). https://doi.org/10.23887/jere.v5i3.34254.

Widodo, A., \& Nursaptin, N. (2020). Problematika Pembelajaran Daring dalam Perspektif Mahasiswa. ELSE (Elementary School Education Journal): Jurnal Pendidikan Dan Pembelajaran, 4(2). https://doi.org/10.30651/else.v4i2.5340.

Yuangga, K. D., \& Sunarsi, D. (2020). Pengembangan Media Dan Strategi Pembelajaran Untuk Mengatasi Permasalahan Pembelajaran Jarak Jauh Di Pandemi Covid- 19. Jurnal Guru Kita, 3(4). https://doi.org/10.24114/jgk.v4i3.19472. 